Article

\title{
Impact of Combined Sewer Systems on the Quality of Urban Streams: Frequency and Duration of Elevated Micropollutant Concentrations
}

\author{
Ulrich Dittmer $^{1, *(\mathbb{D}, \text { Anna Bachmann-Machnik }}{ }^{1} \mathbb{D}$ and Marie A. Launay ${ }^{2}$ \\ 1 Institute of Urban Water Management, University of Kaiserslautern, Paul-Ehrlich-Str. 14, \\ 67663 Kaiserslautern, Germany; anna.bachmann87@outlook.de \\ 2 Kompetenzzentrum Spurenstoffe Baden-Württemberg, University of Stuttgart, Bandtäle 2, 70569 Stuttgart, \\ Germany; marie.launay@koms-bw.de \\ * Correspondence: ulrich.dittmer@bauing.uni-kl.de
}

Received: 4 February 2020; Accepted: 16 March 2020; Published: 18 March 2020

check for updates

\begin{abstract}
Water quality in urban streams is highly influenced by emissions from WWTP and from sewer systems particularly by overflows from combined systems. During storm events, this causes random fluctuations in discharge and pollutant concentrations over a wide range. The aim of this study is an appraisal of the environmental impact of micropollutant loads emitted from combined sewer systems. For this purpose, high-resolution time series of river concentrations were generated by combining a detailed calibrated model of a sewer system with measured discharge of a small natural river to a virtual urban catchment. This river base flow represents the remains of the natural hydrological system in the urban catchment. River concentrations downstream of the outlets are simulated based on mixing ratios of base flow, WWTP effluent, and CSO discharge. The results show that the standard method of time proportional sampling of rivers does not capture the risk of critical stress on aquatic organisms. The ratio between average and peak concentrations and the duration of elevated concentrations strongly depends on the source and the properties of the particular substance. The design of sampling campaigns and evaluation of data should consider these characteristics and account for their effects.
\end{abstract}

Keywords: modeling; CSO; urban drainage; sewer system; trace pollutants; urban runoff; concentration duration frequency curve

\section{Introduction}

Flow regime and water quality of urban streams are strongly influenced by surface runoff from paved areas that are connected to the receiving surface water by pipe systems. Discharge points are stormwater outlets in separate sewer systems and combined sewer overflows (CSOs) in combined systems. With an increasing percentage of paved surfaces, the hydrological response of urban catchments is becoming more rapid, peak flows are increasing, and more pollutants are transported with the runoff. These phenomena are addressed in numerous publications e.g., [1,2]. The associated damage and depletion of aquatic ecosystems has been receiving worldwide attention during the last years and is currently also known under the term "urban stream syndrome" [3].

A more recent concern is the emission of micropollutants (MP) to urban streams, also referred to as trace pollutants or emerging contaminants, and their potential impact on aquatic ecosystems. This is particularly relevant in the case of combined sewer systems where CSO spills do not only transport pollutants from urban surfaces but also wastewater constituents.

Although the relevance of the problem is pointed out by various authors, only few papers deal with this form of pollution of urban streams. Some studies are based on grab sampling in overflowing 
structures or receiving waters (e.g., [4-6]), others used automated samplers to create time series over spilling events [7-10] or to obtain flow weighted event mean concentrations (EMC) [8,11-13]. The specific challenges and impediments of MP sampling during wet weather are discussed by [14].

MP concentrations in CSO discharge vary widely between events and in the course of individual events [15-20]. Any sampling at the CSO structure or in the receiving urban stream only reflects a small section of a randomly fluctuating signal. Calculation of emitted loads and assessment of effects on aquatic ecosystems require continuous data over long periods [2]. This information can be gained through long-term simulations.

Various models are available to simulate the quantity and quality of urban runoff in combined and separate sewers. They are widely applied for dimensioning and management of drainage systems. Yet, calibration of the quality component is a major problem because of the multitude of random influences on pollutant transport [21]. CSO emissions generated by simulation are therefore associated with high uncertainty. This applies particularly to MP as the high analytical costs limit the size of databases for calibration.

The domain of urban drainage models is limited to the quantification of emissions. An assessment of potential ecological effects requires time series of concentrations in the urban stream. For this purpose, models have to account for the hydrology of the undeveloped part of the catchment and of the unpaved surfaces in the urban areas. Following the terminology of [22] we refer to this sub-system as the "natural system," whereas the combination of paved surfaces and underground pipe network is called "artificial system." Both sub-systems show very different hydrological responses, which makes integration into one model difficult (e.g., [23]). The problem becomes even more difficult when receiving water quality should be simulated. In [24] an integrated model of the mixed artificial-natural system that includes the wastewater treatment plant (WWTP) is presented. The model also accounts for transformation processes in the receiving water to simulate concentrations of dissolved oxygen and unionized ammonia. From the application to a case study they conclude that a detailed representation of all model components is necessary to produce satisfactory results.

The study presented in this paper circumvents the problem of model integration by overlaying the simulation results of a sewer system model with discharge measurements from a purely natural catchment. Thus, we constructed a virtual mixed artificial-natural system from two catchments that are separate in reality. Previous studies have identified the proportions of river base flow, WWTP discharge and CSO discharge as suitable proxies for the prediction of MP concentrations $[10,25]$. Based on this knowledge we generate long-term time series of the percentage of base flow, WWTP effluent, and CSO discharge in the receiving water. CSO discharge is further divided into varying proportions of raw wastewater, infiltration water, and urban runoff. River concentrations are calculated by multiplying each component of the discharge with the corresponding concentration derived from previous studies.

The focus of the study is not on specific results for a given case, but on general patterns and phenomena that are typical for wet weather conditions in urban streams affected by combined sewer systems. The main aims are an appraisal of the ecological impacts of micropollutant emissions from CSOs and WWTPs and a comparative assessment of the contribution of each of these pathways to potentially critical situations in the receiving urban stream. Duration and frequency of elevated MP concentrations shall be analyzed to characterize the in situ exposure of organisms quantitatively. Furthermore, conclusions on the design of sampling campaigns shall be drawn from the analysis of the concentration time series.

\section{Materials and Methods}

\subsection{Simulation of the Artificial System}

For the case study the drainage system of the city of Möhringen, Germany was used. This combined sewer system drains into the river Körsch. The total connected area is 859 ha of which $48 \%$ are paved surfaces. The main CSO structures are equipped with storage tanks, where the water is retained for 
subsequent treatment in the WWTP. The total storage volume is $13,095 \mathrm{~m}^{3}$. In relation to the impervious area, this corresponds to $3.2 \mathrm{~mm}$ of surface runoff that can be stored. [26]

Figure 1 shows a schematic overview of the Möhringen sewer system with selected CSO tanks. The corresponding storage volumes and controlled outflows of the simulated CSO tanks are given in Table 1. The overflows of CSO tanks 1-7 are directly connected to the river in the model. The outflows of CSO tanks 8-11 are connected to the WWTP but their overflows are discharged into tributaries that flow into the River Körsch further downstream of the WWTP. The overflows of these tanks are therefore not connected to the model river. The contribution of simple CSO structures without storage to total emissions is negligible.

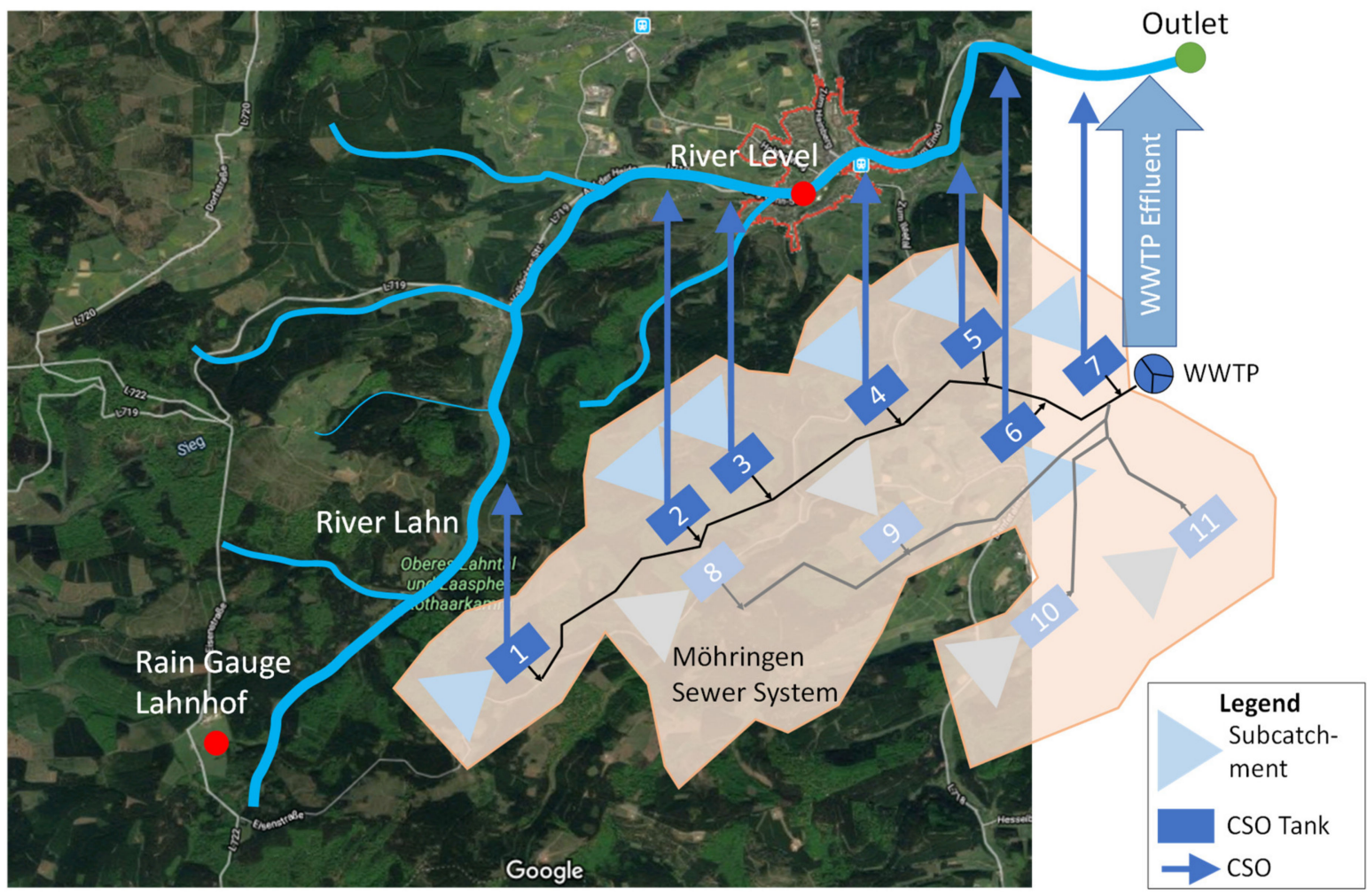

Figure 1. Schematic overview of the overlay of the Möhringen sewer system model and the natural baseflow from the river Lahn; CSO = combined sewer overflow; WWTP = wastewater treatment plant; grey sewer system structures were not considered in the model. (Source: Google Maps)

Table 1. Total connected area, storage volume and controlled outflow of main storage structures in the Möhringen sewer system. Combined sewer overflow tanks are numbered according to Figure 1.

\begin{tabular}{cccc}
\hline $\begin{array}{c}\text { Combined Sewer } \\
\text { Overflow Tank No. }\end{array}$ & $\begin{array}{c}\text { Total Connected Area } \\
\text { (ha) }\end{array}$ & Storage Volume $\mathbf{( m}^{\mathbf{3}} \mathbf{)}$ & $\begin{array}{c}\text { Controlled Outflow } \\
\mathbf{( L / s )}\end{array}$ \\
\hline 1 & 16 & 550 & 304 \\
2 & 61 & 700 & 40 \\
3 & 30 & 390 & 78 \\
4 & 42 & 1300 & 140 \\
5 & 127 & 2300 & 89 \\
6 & 2 & 550 & 121 \\
7 & 12 & 1750 & 1000 \\
8 & 73 & 1200 & 53 \\
9 & 228 & 1665 & 440 \\
10 & 244 & 2290 & 254 \\
11 & 24 & 400 & 23 \\
\hline
\end{tabular}


The Möhringen wastewater treatment plant (WWTP) is designed for 160,000 population equivalents with a daily inflow of $22,985 \mathrm{~m}^{3} / \mathrm{d}$. The inflow to WWTP is limited to $1000 \mathrm{~L} / \mathrm{s}$. The daily water consumption is approx. $125 \mathrm{~L} / \mathrm{d}$. The system is located at 366 to $536 \mathrm{~m}$ above sea levels and the topography is characterized by mild slopes. [26]

The sewer system is represented by a lumped model. The hydrological parameters of the sub-catchments were calibrated in a previous study [26]. The representation of wastewater and infiltration water flow is based on the evaluation of monitoring data of the WWTP influent and of outflow at several CSO tanks. A detailed description of this evaluation and of the calibration process can be found in [26]. The wastewater flow from the population follows different daily patterns on weekdays and weekends. The infiltration water at the inflow of the WWTP is $100 \mathrm{~L} / \mathrm{s}$ and is considered as constant over the entire year. The ratio of infiltration water and wastewater is homogeneous over the entire catchment.

The sewer system model was set up in the simulation software EPA SWMM version 5.1.007 (United States Environmental Protection Agency, Washington, DC, USA) [27]. Simulation was run under kinematic wave conditions with a flow routing time step of $30 \mathrm{~s}$ and a reporting time step of $15 \mathrm{~min}$. Subcatchment slope was derived from catchment topography, subcatchment width was derived from subcatchment geometry. The percentage of impervious area was determined by hydraulic calibration of the sewer system model. The setup parameters of the model can be found in Table S1 in the Supplementary Material. The full model input file and further model details cannot be provided because of confidentiality reasons.

Sewer discharge consists of three components, wastewater $\left(Q_{W W}\right)$, infiltration water $\left(Q_{\text {Inf }}\right)$, and stormwater $\left(\mathrm{Q}_{\mathrm{SW}}\right)$. Each component is marked by a virtual tracer with a constant concentration of $100 \mathrm{mg} / \mathrm{L}$ at the source. The concentrations of these tracers in the CSOs and the effluent of the WWTP thus represent the percentage of the respective component in the total flow. The resulting concentration of MP can thus be calculated by multiplying these percentages with the respective concentrations of the MP in each flow component. Transport of the virtual tracer in the sewers system is modeled in SWMM using the "tanks in series approach" that represent each conduit or storage element as a completely mixed reactor. [28].

The WWTP is implemented in the SWMM sewer system model as a cascade of six completely stirred tanks in series (storage nodes) to reproduce a realistic translation and retention of the substances passing through the WWTP (see Figure S1 in Supplementary Material). The total tank volume used for WWTP implementation is $15,500 \mathrm{~m}^{3}$. The tanks are connected by conduits. A weir after the last storage unit ensures that the water level in the WWTP is kept constant.

Data of a rain gauge within the natural catchment of the river Lahn (station Lahnhof) is used as input for the sewer system model. The data is recorded in $1 \mathrm{~min}$ resolution and the period from 1 January 2004 to 31 December 2004 was used. Therefore, the measured base flow in the river and the discharge from the sewer system are hydrological responses to the same precipitation signal.

\subsection{Overlay with River Base Flow from a Natural Catchment}

Concentrations of MP in the receiving water body are the result of emission by CSO and WWTP effluent and their dilution by the base flow from the natural catchment. However, the base flow was not measured in the specific case of the River Körsch at Möhringen. This is a typical situation, as urban streams are mostly found in headwaters. These river sections are only rarely equipped with gauge stations as monitoring is mostly done on larger scales.

As a substitute for the missing data, the measured time series of a river with a natural catchment of similar size and topography (river Lahn, Germany) was used. Figure 1 shows the overlay of the natural catchment and the sewer system model. The catchment area of the River Körsch at the WWTP outlet is $23.5 \mathrm{~km}^{2}$, while the area of the river Lahn at the gauge station Lahnhof is $25.4 \mathrm{~km}^{2}$. The percentage of urbanized area is 37\% in the real Möhringen catchment and 34\% in the virtual catchment that combines the artificial system of Möhringen with the natural system monitored at the Lahnhof gauge station. 
As hydrology depends on many more parameters than size and urbanization calculated river concentrations do not exactly represent the specific situation of the river Körsch. However, the virtual catchment represents a realistic scenario that can be used to assess the general level of MP concentrations in urban streams and to analyze their variability.

The river section that receives discharge from the artificial system is represented in the SWMM model as an open trapezoidal channel (bottom width $=4 \mathrm{~m}$, top width $=11.6 \mathrm{~m}$, maximum depth $=$ $1.9 \mathrm{~m}$, roughness $=0.25$, length $=5940 \mathrm{~m}$ ) following the natural slope of the Möhringen catchment. The channel is divided into a series of six conduits with different length. Overflows from the sewer system and the effluent from the wastewater treatment plant are directly connected to river nodes. Measured flow data from the Lahn river from the year 2004 (corresponding to the rain data as input for the sewer system simulation) is inserted directly as inflow into the first river node. The time step of the measured data is $15 \mathrm{~min}$.

In analogy to the flow components in the sewer system, the base flow is assigned a virtual tracer concentration $\left(\mathrm{Q}_{\mathrm{B}}\right)$ of $100 \mathrm{mg} / \mathrm{L}$. The mixing of the components is simulated based on the "tank in series approach" in SWMM that represents each conduit as a completely mixed reactor. River quality is evaluated at the outlet of the virtual catchment $100 \mathrm{~m}$ downstream of the WWTP discharge (green dot in Figure 1).

\subsection{Pollution of the Flow Components}

The terms micropollutants or trace substances summarize a big number of substances with very different fields of application and physicochemical properties. General statements on the occurrence and behavior of micropollutants are therefore misleading. Yet, because of the unmanageable number of potentially harmful substances, each measurement or modeling must focus on a selection of substances that represent larger groups.

In a previous study, we have shown that source (wastewater or surface runoff) and elimination in WWTP are the most relevant characteristics that define the transport pathways to the receiving water during dry and wet weather [29]. For this study, we chose four substances that represent combinations of the extremes in terms of these characteristics. The idea behind this selection is that using extremes makes the influence of each characteristic on the results visible. This allows for conclusions on the behavior of other substances with less pronounced characteristics. Another criterion was a reliable database for the estimation of the concentrations.

The painkillers ibuprofen and diclofenac are chosen as indicator parameters originating from wastewater. The difference between these substances lies in their elimination in conventional municipal sewage treatment plants. The elimination of Diclofenac in WWTPs is negligible. It is assumed here that in rainy weather a reduction of the concentrations in the effluent of the WWTP plant results solely from dilution effects. Ibuprofen, on the other hand, is readily degradable and is largely eliminated in the WWTP. However, with an increased inflow into the sewage treatment plant, the elimination efficiency also decreases. It is assumed in this study that the effluent concentration is not changed by the proportion of rainwater passing through the WWTP.

Fluoranthene, from the group of polycyclic aromatic hydrocarbons (PAH) and the urban herbicide mecoprop, are mainly introduced with rainwater into the drainage systems. Fluoranthene has a strong tendency to bind to particles and is thus largely retained in the wastewater treatment plant. Mecoprop is a mainly conservative substance. As diclofenac, the concentration in the effluent of the WWTP results from the mixing of the rainwater and wastewater. In the case of fluoranthene, the higher concentrated rainwater is "diluted" with wastewater.

Table 2 summarizes the properties of the selected substances and the concentrations in the different flow components. The concentrations were derived from the results of intensive sampling in the Möhringen system [9] and data from literature [9,17,30]. 
Table 2. Concentrations of selected substances in the different flow components and in the outflow of the wastewater treatment plant $(\mathrm{WWTP}) ; \mathrm{RW}=$ rainwater; $\mathrm{WW}=$ wastewater.

\begin{tabular}{ccccccc}
\hline Substance & Origin & Degra-Dation & $\begin{array}{c}\text { Rainwater } \\
\text { Concentration } \\
\text { (ng/L) }\end{array}$ & $\begin{array}{c}\text { Wastewater } \\
\text { Concentration } \\
\text { (ng/L) }\end{array}$ & $\begin{array}{c}\text { Conc. } \\
\text { WWTP } \\
\text { Effluent RW } \\
\text { (ng/L) }\end{array}$ & $\begin{array}{c}\text { Conc. } \\
\text { WWTP } \\
\text { Effluent } \\
\text { WW (ng/L) }\end{array}$ \\
\hline Fluoranthene & RW & + & 400 & 160 & 2 & 2 \\
Mecoprop & RW & - & 500 & 30 & 500 & 30 \\
Ibuprofen & WW & + & 0 & 9000 & 40 & 40 \\
Diclofenac & WW & - & 0 & 1700 & 0 & 1700 \\
\hline
\end{tabular}

Constant mean concentrations were used for the flow components wastewater $\left(\mathrm{Q}_{W W}\right)$, infiltration water $\left(\mathrm{Q}_{\text {Inf }}\right)$, and rainwater runoff $\left(\mathrm{Q}_{\mathrm{RW}}\right)$. Concentrations in CSO discharge are solely the result of mixing of these components. Despite the fact that MP concentrations in rainwater runoff are not constant during rain events [31-33], knowledge on occurrence and transport of MP in wet weather flow is too scarce to justify a more detailed modeling approach. [14,34-36]

Infiltration water was assumed to be unpolluted. The elimination in the WWTP plant is described by different constant effluent concentrations for the rainwater and the wastewater fraction. These concentrations represent the effluent of a conventional biological treatment plant. The river base flow from the natural catchment is assumed to be unpolluted concerning the evaluated MP. Transformation in the river plays a minor role at the evaluated temporal and special scale and is therefore neglected.

\section{Results and Discussion}

\subsection{Rainfall and Runoff Regime}

The measured river base flow of the river Lahn and the precipitation at the rain gauge Lahnhof from January until December 2004 is shown in Figure 2. The average annual precipitation sum at the Lahnhof rain gauge is $1043 \mathrm{~mm}$ (2000-2010). The yearly precipitation in 2004 is $835 \mathrm{~mm}$.

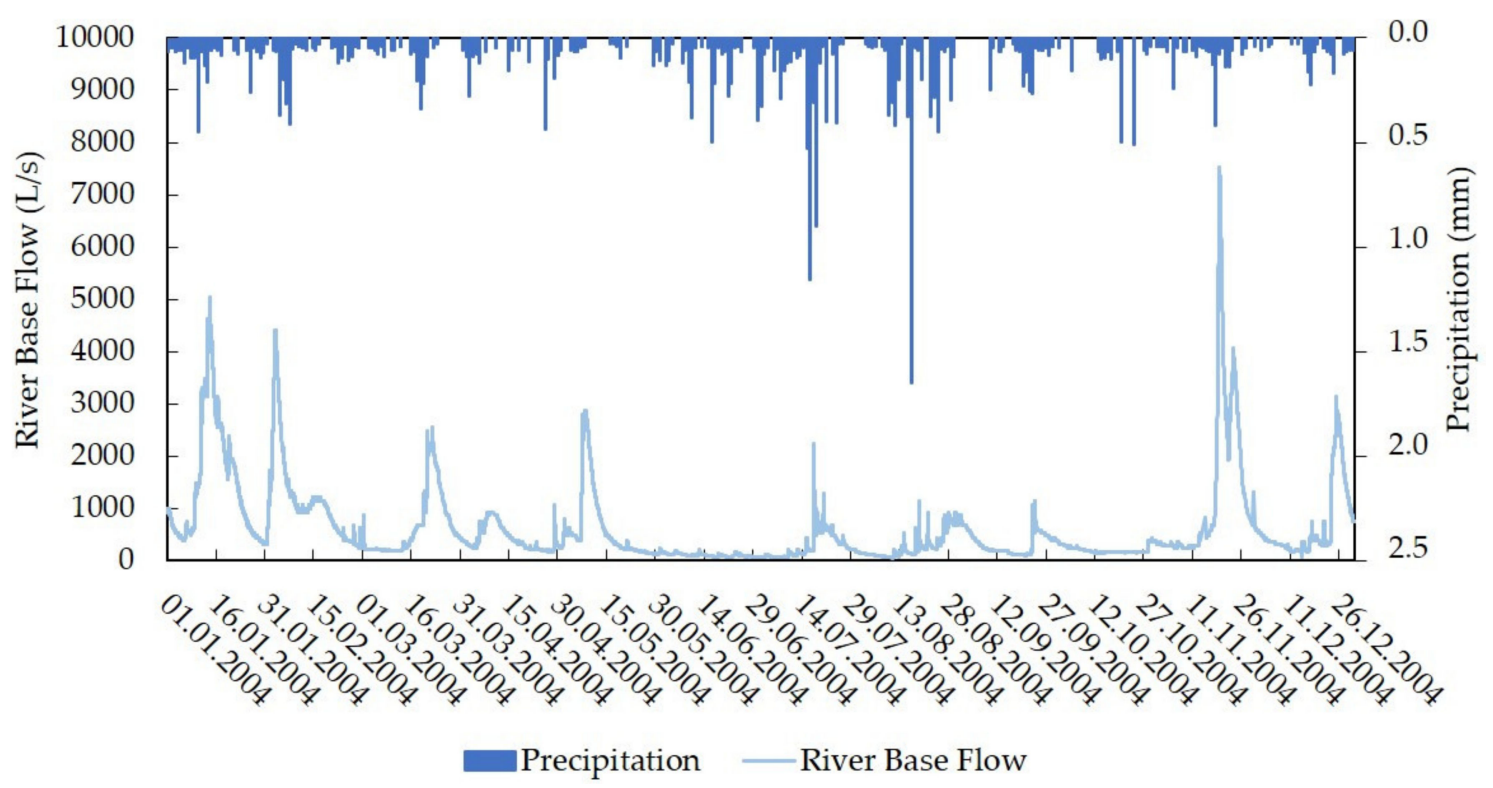

Figure 2. Hydrograph of the natural system for the year 2004.

The duration curve of the total river flow (including CSO and WWTP effluent) and the base flow from natural catchment is shown in Figure 3. 


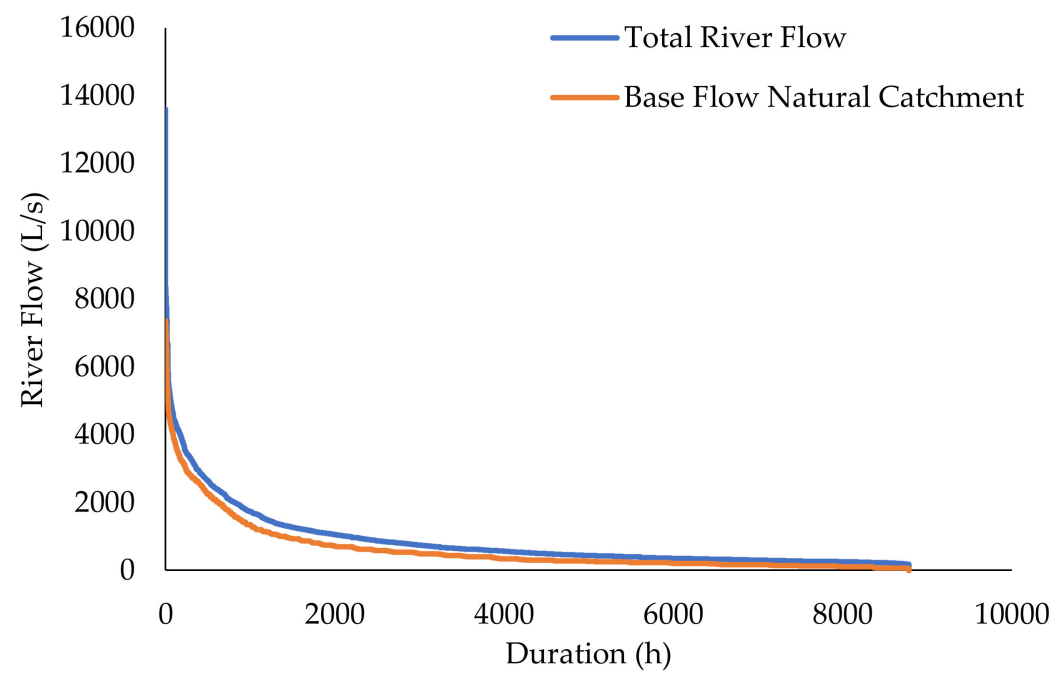

Figure 3. Duration curve of total river flow (including CSO and WWTP effluent) and base flow from natural catchment.

The average monthly base flow from the natural catchment of the river Lahn is shown in Figure 4 . The discharge shows a distinct yearly pattern with low values from April to November and higher ones during winter from December to March.

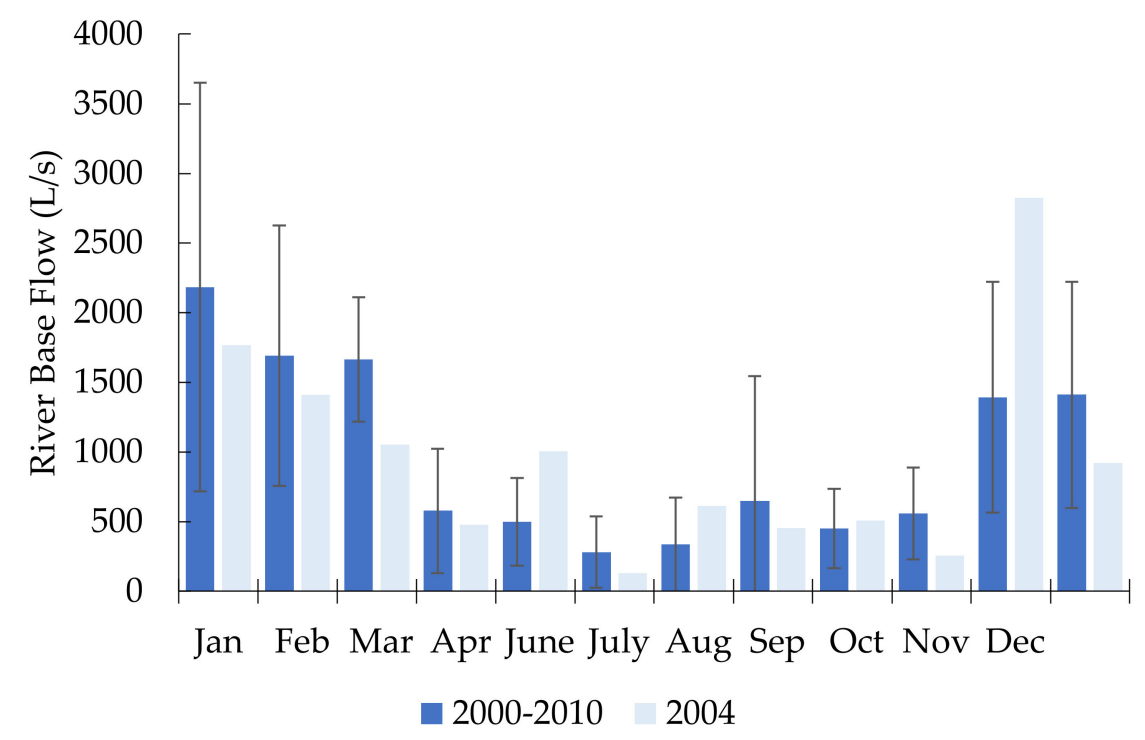

Figure 4. Monthly average base flow in the river Lahn from 2000-2010 (average value, whisker = \pm standard deviation) and 2004 .

\subsection{Example of Mixing Ratios and Resulting Concentrations}

The resulting concentrations in the river downstream of the discharge points of the CSOs and the WWTP (system outlet in Figure 1) for an exemplary overflow event of the system from 22-25 September are shown in Figure 5. The total precipitation of this event is $24 \mathrm{~mm}$ with an average rain intensity of $0.4 \mathrm{~mm} / \mathrm{h}$ and a maximum rain intensity of $11 \mathrm{~mm} / \mathrm{h}$.

During this event, the CSO tanks in the sewer system start filling on September 22nd around $5 \mathrm{pm}$. The first overflows from the system start on 22 September at $8 \mathrm{pm}$ at tank 7 . The last overflow from the system ends at 5 pm on 23 September. During this rain event, a total of 2 (no. 3 and no. 7) CSO tanks discharge into the river. A total volume of $21,000 \mathrm{~m}^{3}$ is emitted. 

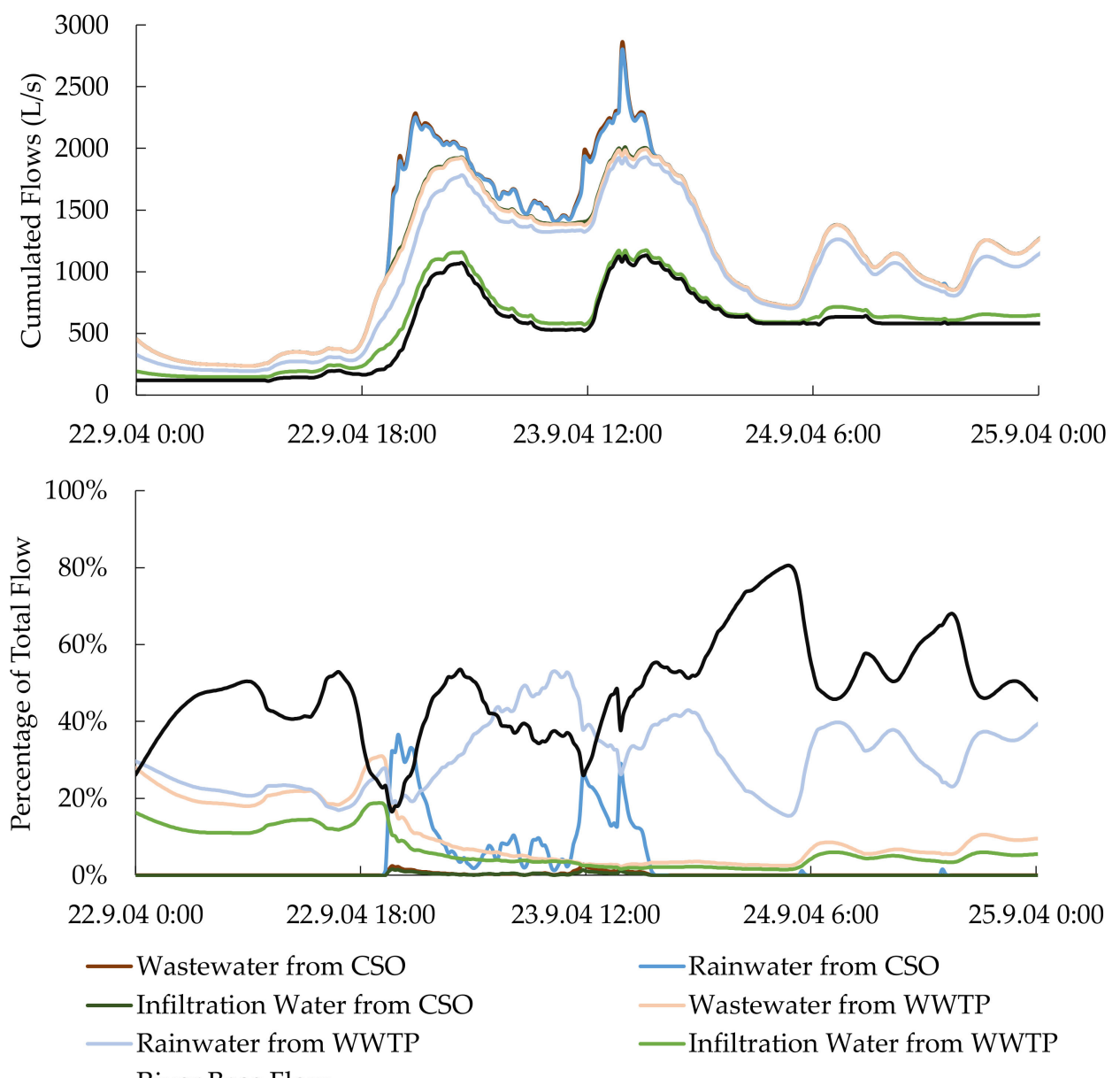

- River Base Flow

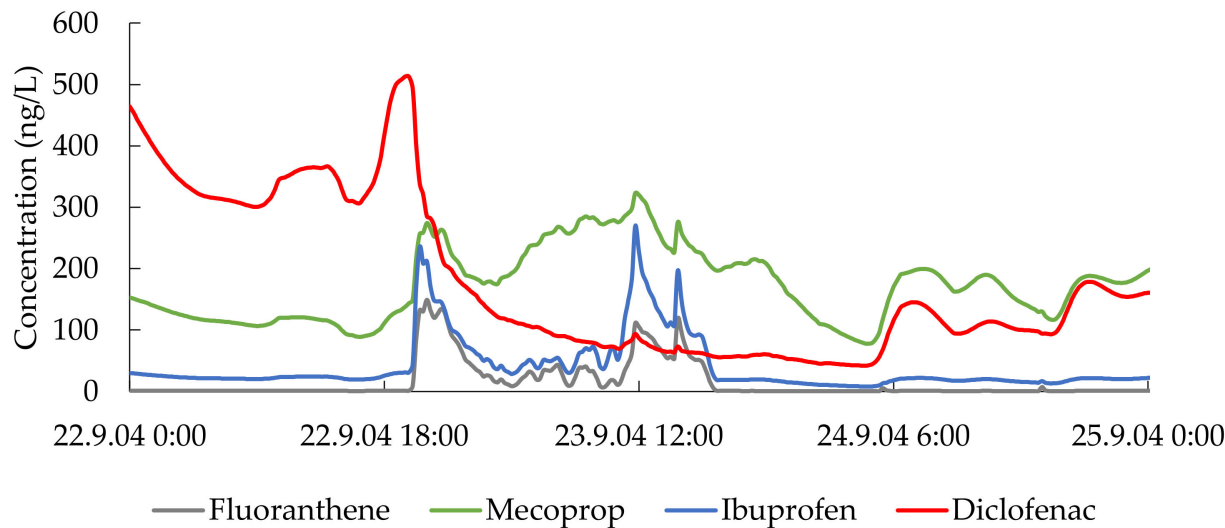

Figure 5. Simulated timeseries of flows (top), total flow percentage (middle), and corresponding micropollutant concentrations (bottom) for event from 22 September until 25 September, 2004; $\mathrm{CSO}=$ combined sewer overflow, $\mathrm{WWTP}=$ wastewater treatment plant.

The graph on top shows the cumulated flows of all components during this event. The proportion of infiltration water in the river during dry weather conditions is approx. $20 \%$, the wastewater proportion is $30 \%$. A proportion of $50 \%$ of the total river flow during dry weather is the catchment's natural baseflow.

In the displayed section from 22-25 September a rainwater proportion, which was treated in the WWTP of around $20 \%$ is already flowing in the river, lowering the infiltration water proportion to $10 \%$ and the wastewater proportion to $20 \%$ (Figure 5, middle). Starting at $5 \mathrm{pm}$ on 22 September nd the outflow of the WWTP slowly increases mainly because of the increased amount of rainwater treated in 
the WWTP. At 8 pm on 22 September, the first system overflows reach the observation point at the system outlet. At the same time, the baseflow from the natural catchment also increases. However, this increase is much slower than the increase of the flow from the urban system. At 8:30 pm the base flow from the natural catchment decreases to only $17 \%$ of the total flow at the observation point. The rainwater proportion treated in the WWTP is $20 \%$, the untreated rainwater is around $30 \%$ at that time. The maximum proportion of untreated wastewater within the river during this event is $3 \%$. In the entire year 2004, a maximum proportion of untreated wastewater within the river of $5 \%$ is reached in July during an overflow event with a very low river base flow of only $200 \mathrm{~L} / \mathrm{s}$.

On 23 September at 5:30 pm no flow proportions from CSOs are detected at the observation point anymore. After $6 \mathrm{pm}$ the outflow of the WWTP decreases until the base flow from the natural catchment increases until $80 \%$. Afterward the base flow stabilizes at around $600 \mathrm{~L} / \mathrm{s}$ which is higher than the flow level before the rain event $(\approx 140 \mathrm{~L} / \mathrm{s})$.

The concentrations of the indicator micropollutants (Figure 5, bottom) result from the multiplication of the ratios of the wastewater components in the river with the corresponding micropollutant concentration in this pathway. The river base flow and infiltration water were assumed to be unpolluted and a concentration of $0 \mathrm{ng} / \mathrm{L}$ was assigned to each micropollutant.

The concentration of diclofenac is determined only by the dilution of wastewater under dry weather conditions. As a conservative substance, no degradation takes place in the WWTP. At the beginning of the rain event the concentration of diclofenac is $300-500 \mathrm{ng} / \mathrm{L}$ in the river at the observation point corresponding to a wastewater proportion of $20-30 \%$. Starting from $8 \mathrm{pm}$ the wastewater at the observation point is increasingly diluted resulting in lower concentrations of around $50 \mathrm{ng} / \mathrm{L}$ of diclofenac in the river. The emitted load stays constant over time.

The urban herbicide mecoprop is not degraded in the WWTP. Because of the increased entry with urban runoff, the concentration profile is quantitively inverse from diclofenac. Only a small amount of mecoprop is discharged through the treatment plant during dry weather, resulting in a concentration of around $100 \mathrm{ng} / \mathrm{L}$ at the observation point. With increasing rainwater runoff, this concentration increases to over $300 \mathrm{ng} / \mathrm{L}$. Since diclofenac and mecoprop are both not eliminated in the WWTP, it is irrelevant whether the discharge into the receiving water takes place via CSO or WWTP.

Ibuprofen and fluoranthene behave differently, both substances are effectively eliminated in the WWTP. The WWTP effluent concentration of fluoranthene is unaffected by the increased inflow to the WWTP during wet weather. In the model, it is assumed that the particle retention in secondary clarifier continues to work well also during high hydraulic loading. On the contrary, the CSO is heavily contaminated with PAHs such as fluoranthene. Short-term concentration peaks of fluoranthene are therefore observed at the system outlet. Despite a different transport path, Ibuprofen behaves similarly. Concentration peaks in the river are also directly linked to CSO events for this substance.

\subsection{Annual Balance of Volume Flow and Pollutant Loads}

In $200473 \%$ of the total flow recorded at the observation point is base flow from the natural catchment (see Figure 6). Only 1.5\% are rainwater, wastewater, and infiltration water discharged via combined sewer overflows. A proportion of $10 \%$ of the total river flow is treated wastewater, $10 \%$ is rainwater treated in the wastewater treatment plant, and $6 \%$ is infiltration water. The outflow of the wastewater treatment plant makes a total of $26 \%$ of the total flow at the observation point in 2004. 


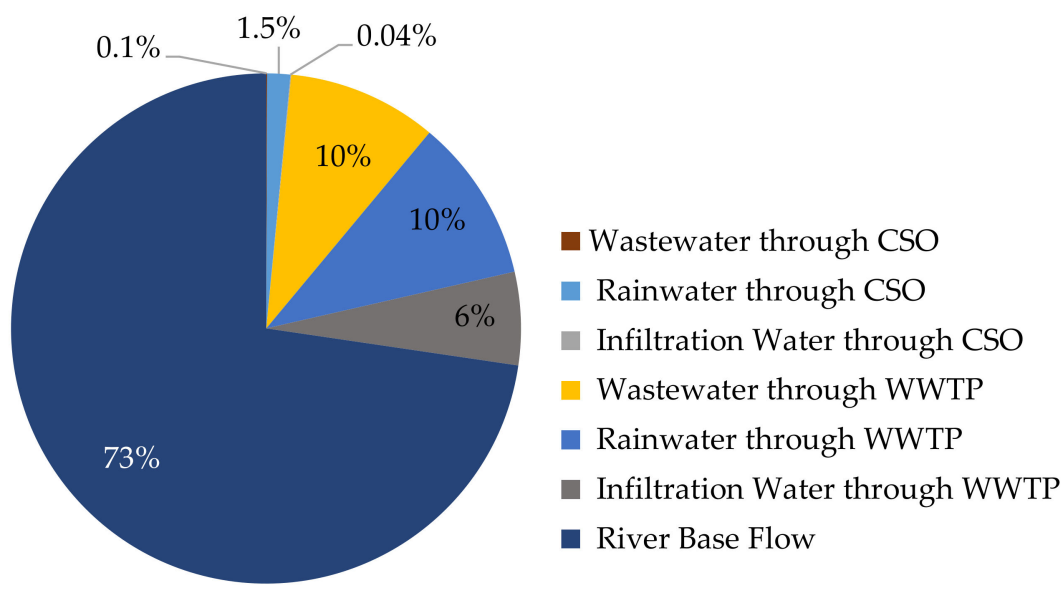

Figure 6. Contribution of different emission pathways to total emitted flow; $\mathrm{CSO}=$ combined sewer overflow, WWTP = wastewater treatment plant.

Multiplication of the volume of the flow components with the corresponding MP concentrations gives the annual loads shown in Figure 7. As expected, diclofenac that originates from wastewater and is not well eliminated in the WWTP is mainly emitted via the WWTP effluent. In contrast, fluoranthene that is transported mainly by surface runoff and is almost completely eliminated in the WWTP is emitted mainly via CSOs. In the case of mecoprop, the poor elimination in the WWTP is the dominating influence concerning the pathway. Although ibuprofen is only transported with the wastewater, it is emitted to one-third by CSO.

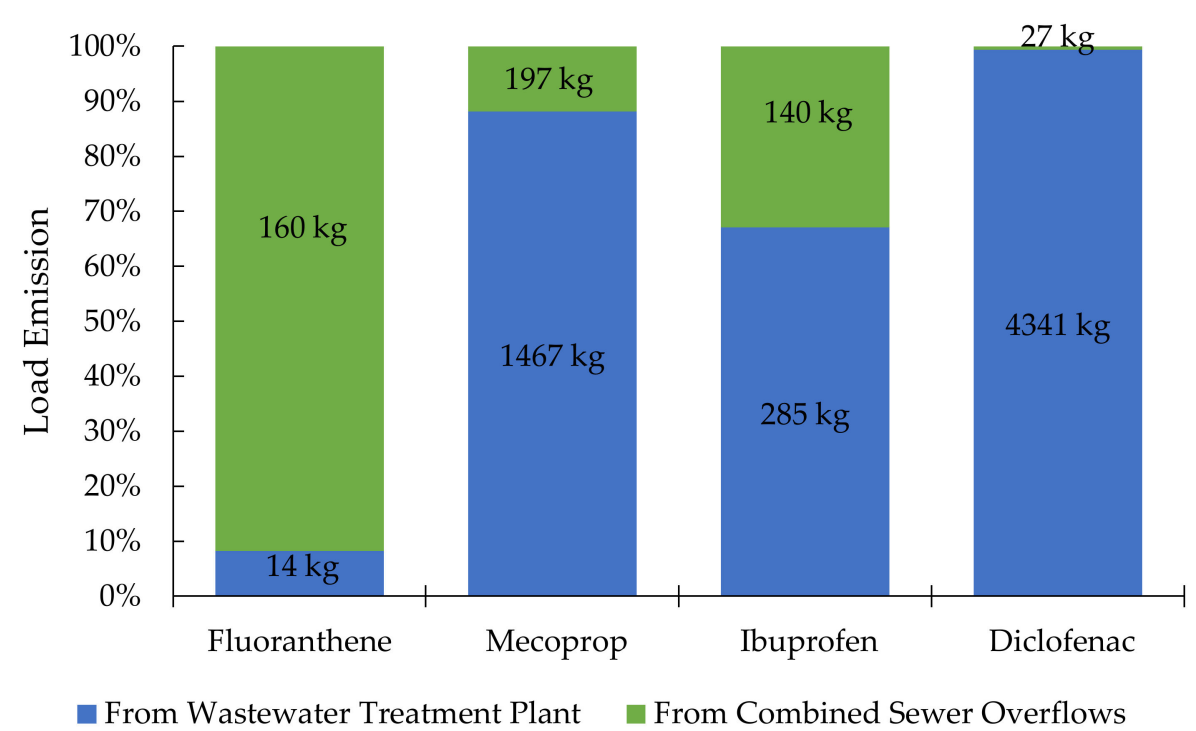

Figure 7. Annual pollutant loads emitted by CSO discharge and WWTP effluent.

The total balance of the MP emission pathways is strongly determined by MP concentrations in each of the flow components (see Table 2). The data for MP concentrations in rainwater runoff from paved areas are scarce and show wide and random variability between sites and events as well as in the course of each event. $[9,17,37,38]$ Therefore, MP concentrations within this flow component are particularly uncertain. To assess the importance of this uncertainty, concentrations of fluoranthene and mecoprop in rainwater runoff were varied within a range derived from published data. Fluoranthene was set to $10 \mathrm{ng} / \mathrm{L}$ and $3200 \mathrm{ng} / \mathrm{L}$ as found in [17,18,38,39] and mecoprop to $1 \mathrm{ng} / \mathrm{L}$ to $6900 \mathrm{ng} / \mathrm{L}$ as found in $[17,39]$.

The total emitted load of both substances increases linearly with increased rainwater runoff concentration. Figure 8 shows the contribution of the CSO emissions to the total emitted load depending 
on the concentrations of fluoranthene and mecoprop in rainwater runoff. For fluoranthene the proportion of CSO load increases with rainwater runoff concentration. For fluoranthene concentrations higher than $2000 \mathrm{ng} / \mathrm{L}$ more than $98 \%$ of the load is discharged via CSO.

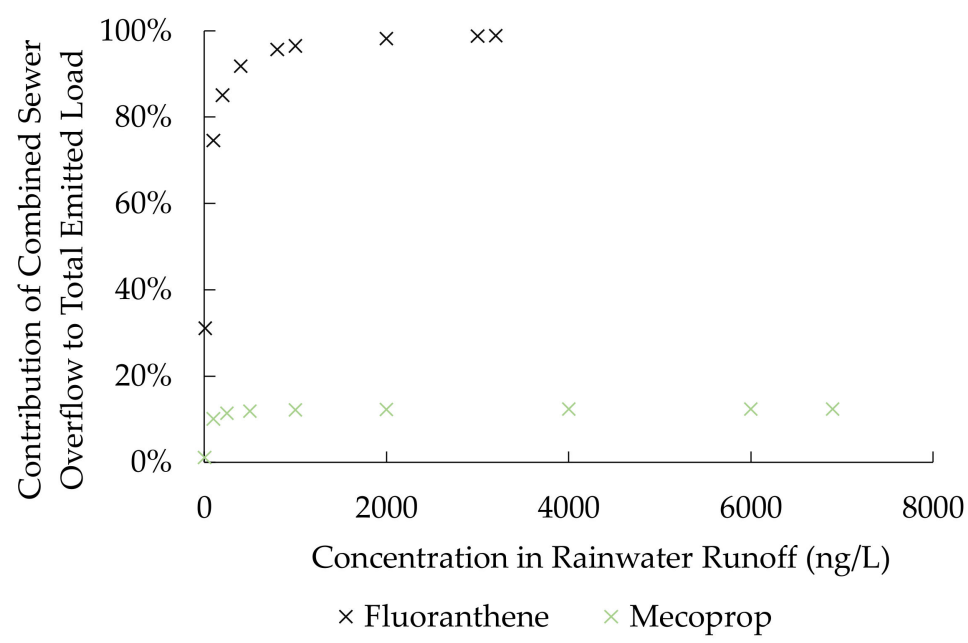

Figure 8. Influence of fluoranthene and mecoprop concentrations in rainwater runoff on the contribution of combined sewer overflow to the total emitted load.

In contrast to fluoranthene, mecoprop is not degraded in conventional WWTPs and during rain events and it is discharged from the WWTP with rainwater runoff concentration. Therefore, the contribution of CSOs does not reach more than 13\% of the total emitted load. The WWTP remains the main entry path to the river for mecoprop.

\subsection{Variability of Concentrations and Mass Flow Rates}

An overview of the resulting concentrations throughout the entire observation period is shown in the concentration duration curves of Figure 9. The curve shows for which time (cumulated) a certain concentration has been reached or exceeded at the observation point in the river. The highest concentrations of diclofenac occur at the area outlet during dry weather with low base flow. As the base flow increases, the concentrations in the river decrease because of dilution. The proportion of wastewater in the river varies by up to $48 \%$ under dry weather conditions. The concentration of diclofenac in dry weather varies between 300 and $700 \mathrm{ng} / \mathrm{L}$. Low average concentrations of $100 \mathrm{ng} / \mathrm{L}$ can only be reached when the wastewater is additionally diluted during rain events.

Ibuprofen and fluoranthene are eliminated in the WWTP. Significant concentration peaks in the river therefore occur only during CSO events. In 2004 CSOs in the system occurred during $234 \mathrm{~h}$. This is clearly reflected in the concentration duration curves showing a strong peak in the first $234 \mathrm{~h}$. The concentration duration curve of mecoprop is less pronounced but more concave than the curve of diclofenac. WWTP effluent contains $30 \mathrm{ng} / \mathrm{L}$ of mecoprop during dry weather. Higher values in the receiving water indicate the influence of stormwater in WWTP effluent or CSO events. The limit value of the German Surface Waters Ordinance (OGewVO 2016) for the annual average mecoprop concentration of $100 \mathrm{ng} / \mathrm{L}$ exceeds during $1500 \mathrm{~h}$ in 2004.

Besides monitoring river water quality, sampling may also aim to determine loads discharged from urban areas. The duration curves clearly show that time proportional sampling in an urban stream is prone to underestimate pollution related to storm events. Table 3 shows the values of volume and time proportional mean concentrations and the difference between the two approaches. This is the systematic deviation based on data in 15 min intervals over the entire year. It is not to be confounded with the uncertainty of sampling due to limited resolution in time or limited sampling periods. The results show that time proportional sampling systematically overestimates the load of diclofenac. The time proportional approach does not account for the fact, that lower concentrations are 
associated with large volumes. On the contrary, loads of fluoranthene are underestimated because they occur mainly during the short time of CSO events when the flow is high.

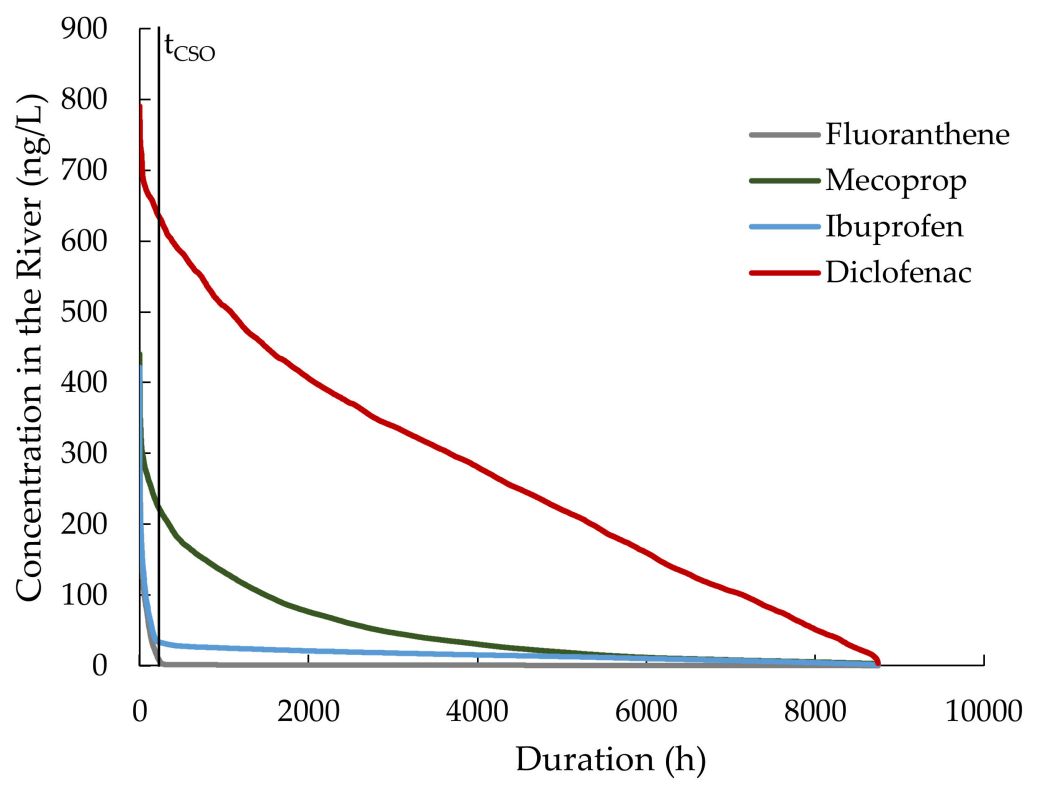

Figure 9. Concentration duration curves downstream of the WWTP for the assessed micropollutants.

Table 3. Annual mean MP concentrations using time proportional and flow proportional average (positive differences indicate an overestimation by time proportional approach).

\begin{tabular}{cccc}
\hline Substance & $\begin{array}{c}\text { Mean Concentration } \\
\text { Flow Proportional (ng/L) }\end{array}$ & $\begin{array}{c}\text { Mean Concentration } \\
\text { Time Proportional (ng/L) }\end{array}$ & Difference (\%) \\
\hline Fluoranthene & 6.5 & 2.6 & $-60 \%$ \\
Mecoprop & 61.9 & 51.1 & $-18 \%$ \\
Ibuprofen & 15.9 & 16.3 & $3 \%$ \\
Diclofenac & 162.6 & 272.9 & $68 \%$ \\
\hline
\end{tabular}

\subsection{Impact of Combined Sewer Overflow on River Quality}

Figure 10 shows the relationship between water concentrations and total discharge at the observation point. Concentrations during CSOs are indicated with circles.

High concentrations of the drug diclofenac occur at low river flows when the wastewater is only sparsely diluted by other flow components. Concentrations in the river during overflow and without CSOs in the system are very close (780 ng/L and $790 \mathrm{ng} / \mathrm{L})$.

Mecoprop shows a similar behavior. Since this substance, such as diclofenac, is not retained in the WWTP, the river concentration results from the dilution of the rainwater runoff from the urban areas with wastewater, infiltration water, and the river base runoff. Maximum concentrations of up to 320 $\mathrm{ng} / \mathrm{L}$ are reached when no overflow from the sewer system occurs. Highest river concentrations of up to $440 \mathrm{ng} / \mathrm{L}$ occur during CSO events.

Like mecoprop, the PAHs (here: fluoranthene) are mainly transported with the rainwater runoff. Without any overflow from the system the fluoranthene concentration in the river is very low (around $10 \mathrm{ng} / \mathrm{L}$ ) except for few observations up to $150 \mathrm{ng} / \mathrm{L}$ during low river flow. The reason for these low values is the high elimination rate in the WWTP for fluoranthene even during wet weather. Higher concentrations of up to $350 \mathrm{ng} / \mathrm{L}$ are only reached during CSOs. This is due to the low concentration in the effluent of the treatment plant, which is achieved even with mixed water drainage.

Without overflows from the system, the maximum river concentration of ibuprofen is $50 \mathrm{ng} / \mathrm{L}$. This can be explained by the good removal efficiency for ibuprofen in the WWTP too. During CSO events high concentrations in the river of up to $420 \mathrm{ng} / \mathrm{L}$ are reached. 
Interpreting the scatter plots one has to take into account that CSO events occur only during a very short fraction of time (2.6\% in the case of Möhringen). More meaningful, but less intuitive, are cumulated frequency curves of river concentrations during dry weather, wet weather and during CSO events (see Figure S2 in Supplementary Material).
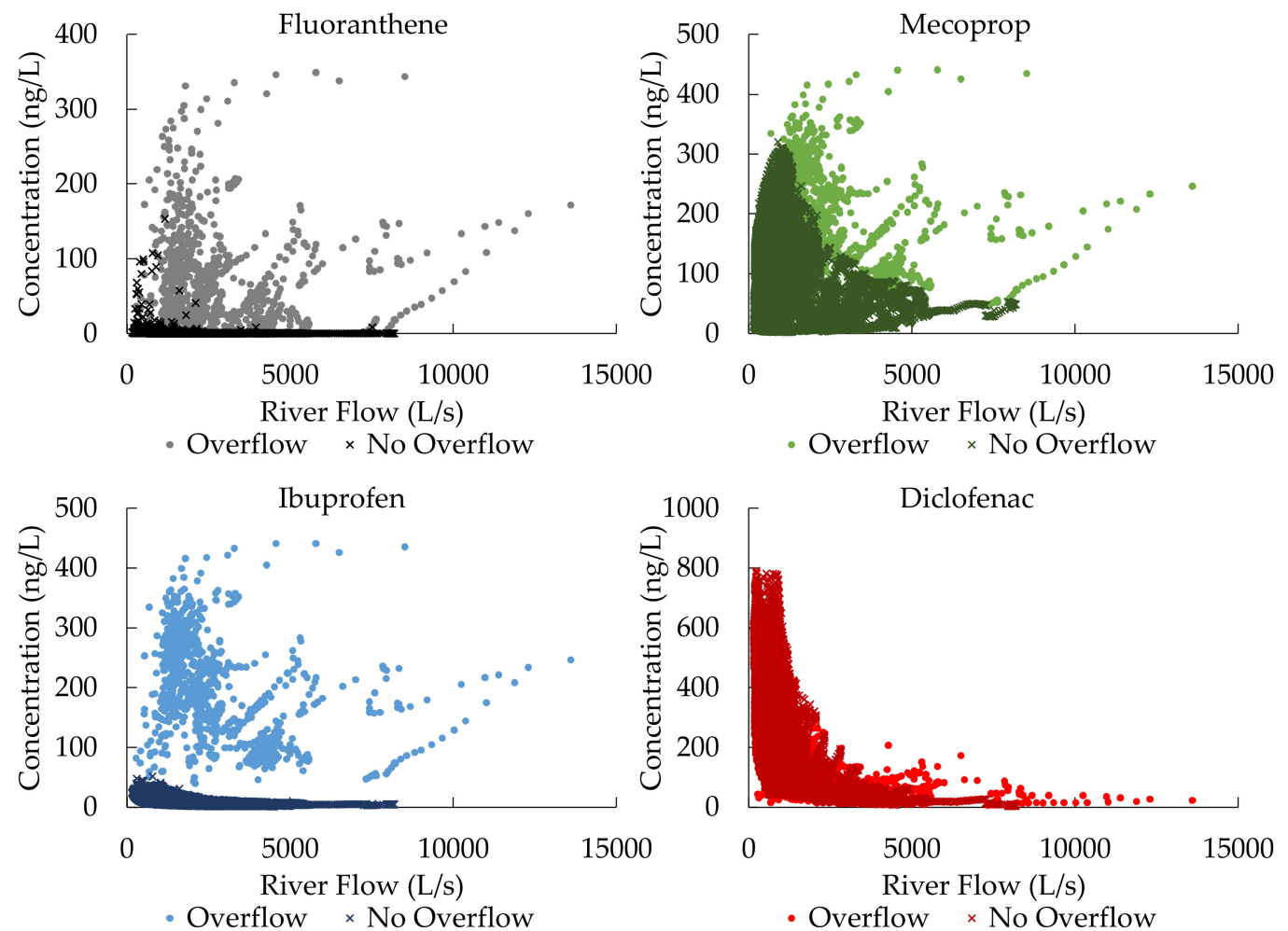

Figure 10. Micropollutant concentrations plotted over river flow downstream of the wastewater treatment plant. "Overflow" marks value during overflow events (overflow duration: $234 \mathrm{~h}$, corresponding to $2.7 \%$ of total time).

\subsection{Concentration-Duration-Frequency Relation}

The impact of critical situations on aquatic organisms or entire ecosystems depends on the intensity of the stressor (here: concentration) and on the duration of the exposure. To assess the impact of emissions from sewers systems and WWTP concentration-duration-frequency (CDF) relations are analyzed as shown in Figure 11. This is done by processing the complete time series of the river concentration in three steps:

(1) Produce time series of the moving average over relevant durations D (here: $15 \mathrm{~min}$ to $48 \mathrm{~h}$ ).

(2) Sort each time series in descending order.

(3) Select the $n$-th highest value for the frequency $n$ (events/year), (here: $n=1$ and $n=5$ ).

In step 3 values should be selected from independent events to get meaningful results. The time difference between the values has to be larger than $\mathrm{D}$.

Figure 11 shows the results for the system outlet (downstream of WWTP) and another reference point immediately upstream of the WWTP. The figures show concentrations that have been reached or exceeded continuously over a time $\mathrm{D}$ with the frequency $\mathrm{n}$.

For diclofenac, we see a big difference in concentration levels upstream and downstream of the WWTP, which is expected as this substance is continuously released by the WWTP. Duration and frequency have only a minor influence. This indicates that the five highest values all occur during a similarly low base flow. In contrast to CSO spills low water extremes develop over a longer time. We 
therefore see no effect in the observed range of durations. The highest concentrations observed over several days continuously is around three times higher than the time averaged concentration.

For fluoranthene, we see a strong influence of the duration and lower but still significant influence of the frequency. High peaks are limited to short events. This can be explained by the fact that they are generated from CSO events. The WWTP effluent dilutes the emission and leads to lower concentrations downstream. Concentrations 100 times above the average $(2.6 \mathrm{ng} / \mathrm{L})$ occur for up to three hours in a row. In the simulated year, concentrations higher than 30 times the average were observed five times for $12 \mathrm{~h}$.

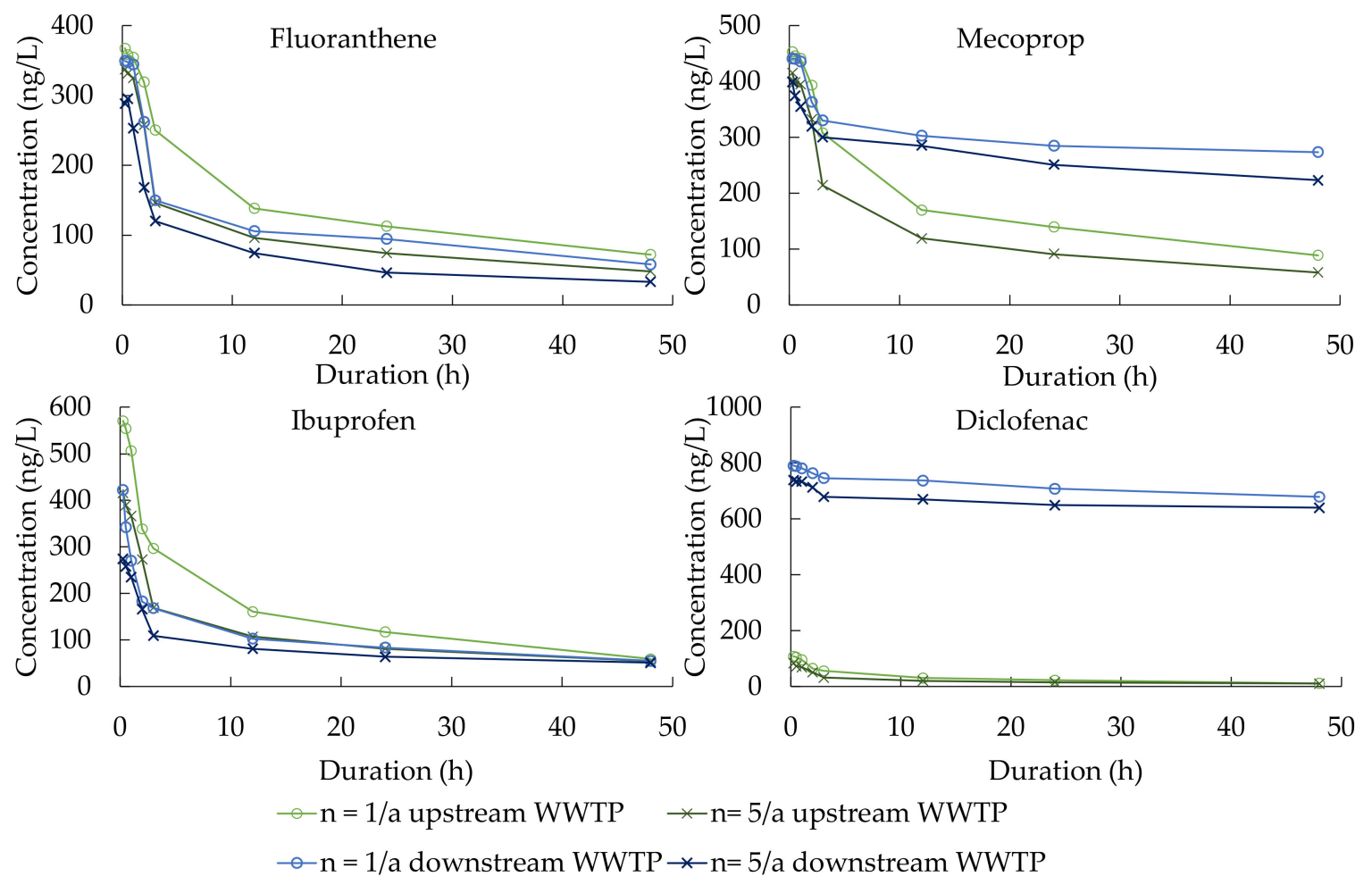

Figure 11. Concentration-duration-frequency curves in the river immediately upstream and downstream of the wastewater treatment plant (WWTP). The curves indicate the concentration that is exceeded continuously over the time $\mathrm{D}$ with the frequency $n$.

Mecoprop and ibuprofen also show a strong influence of short events $(\mathrm{D}<3 \mathrm{~h})$, presumably by CSO spills. For mecoprop, concentration downstream of the WWTP is higher than upstream for events longer than three hours as there is no relevant elimination in the WWTP. Ibuprofen shows higher concentrations upstream of the WWTP as the effluent has much lower concentrations and therefore dilutes the emissions from CSO. Concentrations that are exceeded five times in the simulated year over $12 \mathrm{~h}$ in a row are four to five times above the average for both substances.

The influence of the rainwater concentration of fluoranthene and mecoprop on the CDF relation downstream the WWTP is shown in Figure S3 in the Supplementary Material. Based on the ranges found in literature (see Section 3.3) rainwater runoff concentrations of fluoranthene were increased to $3200 \mathrm{ng} / \mathrm{L}$ and to $6900 \mathrm{ng} / \mathrm{L}$ for mecoprop. On the time scale of several hours up to 2 days maximum concentrations in the receiving water are directly related to heavy rain events. Discharge in the urban stream consists mainly of rainwater runoff. Therefore, the level of CDF curves changes almost linearly with the rainwater runoff concentration, while the form of the curve remains the same.

Setting the concentration of rainwater runoff to values at the lower end of the observed range decouples receiving water quality from rain events. Construction of rain event related CDF curves makes no sense under these conditions. Concentrations in the urban stream vary mainly on a larger time scale with the ratio between WWTP effluent base flow. 
The comparison of potentially critical events with the average values reveals that dry weather in combination with time proportional evaluation give no indication of the acute impact on the ecosystem. However, the time scale of effects on aquatic organisms and their relation to the frequency of occurrence requires further research on the side of ecotoxicology.

\section{Conclusions}

The results of the simulation show how strongly the behavior of micropollutants in urban water depends on their origin and properties (here: retention in the WWTP). General statements on the behavior of all micropollutants are therefore misleading. For the conducted simulation study, indicator parameters with distinct characteristics were chosen. The results can be transferred to other substances if their specific properties are taken into account.

The precipitation characteristics directly affect the concentrations of micropollutants in urban waters. For the evaluation of the chemical status, the conditions during wet weather are most important, since most of the legally regulated substances originate from surface runoff. However, water samples are usually drawn at previously fixed time intervals or random over time. Samples of the river water during wet weather are therefore rarely examined. Water monitoring for evaluation of the waterbodies chemical status takes place not only temporally, but also spatially on a much coarser scale. Urban catchment areas are not specifically investigated. The results of the simulation suggest that even urban water bodies that may appear uncritical on a larger level, spatially (urban areas) and temporally (wet weather) massive violations of EQN concentrations may occur. It remains unclear how such stressing factors can be assessed considering the aquatic ecology.

Neglecting wet weather runoff also leads to serious misinterpretations when grab sampling is used to estimate long-term load emissions. The extrapolation underestimates loads of biocides and PAH, which are mainly transported with the wet weather runoff. Even wastewater-borne substances that are partially degraded in the wastewater treatment plants enter the receiving water bodies increasingly during wet weather.

To adequately classify the measured concentrations and the influence of the sewage system, water sampling in urban streams should generally take place more intensively during wet weather. If the proportions of all relevant flow components within the river were known at the time of sampling, the individual pathways could be extrapolated by observing or simulating flow volumes alone.

However, full monitoring of all combined sewer overflows is not feasible with reasonable effort. Alternatively, the proportions of treated and untreated wastewater in the river can be estimated by comparing concentrations of indicator substances under dry weather conditions in the inflow and outflow of the WWTP.

Mean values (time or flow weighted) of samples from urban streams do not reflect the potential impact of stress events on aquatic organisms. In discussions with ecotoxicologists, we have found CDF curves to be a suitable visualization for the communication across disciplines. However, the robustness of these curves against uncertainties in model structure and parameter settings needs to be investigated further. In future studies we want to use CDF curves to evaluate and compare different options for stormwater management and treatment.

The study assumes that the proportions of treated and untreated runoff and wastewater dominate micropollutant concentrations in urban streams. This hypothesis is based on our own previous studies and on literature. However, it needs to be tested in future studies when more sampling data are available.

Supplementary Materials: The following are available online at http://www.mdpi.com/2073-4441/12/3/850/s1, Figure S1: Propagation of inert tracer through the wastewater treatment plant (WWTP) during wet weather $($ WWTP inflow $=1000 \mathrm{~L} / \mathrm{s})$, Figure S2: Cumulative frequency distributions for fluoranthene, mecoprop, ibuprofen and diclofenac in the river downstream the wastewater treatment plant. The percentage on the $y$-axis corresponds to the time of the state lasts. All: total simulation period $(8760 \mathrm{~h})$, rainy weather: stormwater in the WWTP effluent $>5 \%$ (5935 h), overflow: CSO events (234 h), Figure S3: Concentration-duration-frequency curves in the 
river immediately downstream of the wastewater treatment plant for fluoranthene and mecoprop with varying rainwater (RW) concentrations, Table S1: Setup parameters for the SWMM sewer system model.

Author Contributions: Conceptualization, U.D.; methodology, U.D. and A.B.-M; software, A.B.-M; validation, U.D., A.B.-M and M.A.L.; formal analysis, U.D. and A.B.-M; investigation, M.A.L.; resources, U.D.; writing - original draft preparation, U.D. and A.B.-M.; writing—review and editing, U.D. and A.B.-M.; visualization, A.B.-M.; supervision, U.D. All authors have read and agreed to the published version of the manuscript.

Funding: This research received no external funding.

Acknowledgments: The authors would like to thank Amin Ebrahim Bakshipour for his support in implementation of the wastewater treatment plant and Mehari Goitom Haile for the permission to use his calibrated sewer system model of the Möhringen catchment. Furthermore, we would like to thank the "Landesamt für Natur, Umwelt und Verbraucherschutz Nordrhein-Westfalen LANUV" (Regional Office for Nature, Environment and Consumer Protection) for the measured data used in this study as well as the Ministry of the Environment, Climate Protection, and the Energy Sector Baden-Württemberg.

Conflicts of Interest: The authors declare no conflict of interest.

\section{References}

1. Walsh, C.J.; Fletcher, T.D.; Ladson, A.R. Stream restoration in urban catchments through redesigning stormwater systems: Looking to the catchment to save the stream. J. N. Am. Benthol. Soc. 2005, 24, 690-705. [CrossRef]

2. Fletcher, T.D.; Andrieu, H.; Hamel, P. Understanding, management and modelling of urban hydrology and its consequences for receiving waters: A state of the art. Adv. Water Resour. 2013, 51, 261-279. [CrossRef]

3. Walsh, C.J.; Roy, A.H.; Feminella, J.W.; Cottingham, P.D.; Groffman, P.M.; Morgan, R.P. The urban stream syndrome: Current knowledge and the search for a cure. J. N. Am. Benthol. Soc. 2005, 24, 706-723. [CrossRef]

4. Phillips, P.; Chalmers, A.T. Wastewater effluent, combined sewer overflows, and other sources of organic compounds to Lake Champlain. J. Am. Water Resour. Assoc. 2009, 45, 45-57. [CrossRef]

5. Petrie, B.; Barden, R.; Kasprzyk-Hordern, B. A review on emerging contaminants in wastewaters and the environment: Current knowledge, understudied areas and recommendations for future monitoring. Water Res. 2015, 72, 3-27. [CrossRef]

6. Kasprzyk-Hordern, B.; Dinsdale, R.M.; Guwy, A.J. The removal of pharmaceuticals, personal care products, endocrine disruptors and illicit drugs during wastewater treatment and its impact on the quality of receiving waters. Water Res. 2009, 43, 363-380. [CrossRef]

7. Meyer, B.; Bierl, R.; Keßler, S.; Krein, A. Untersuchung von Niederschlagswassermanagementsystemen und deren stofflicher Wirkung auf den Vorfluter mittels hochaufgelöster Ereignisbeprobung. Hydrol. Wasserbewirtsch. 2013, 57, 164-173.

8. Launay, M.; Kuch, B.; Dittmer, U.; Steinmetz, H. Dynamics of selected micropollutants during various rain events in a highly urbanised catchment. In Proceedings of the 13th International Conference on Urban Drainage, ICUD, Kuching, Malaysia, 7-12 September 2014.

9. Launay, M. Organic Micropollutants in Urban Wastewater Systems during Dry and Wet Weather-Occurrence, Spatio-temporal Distribution and Emissions to Surface Waters. Ph.D. Thesis, University of Stuttgart, Stuttgart, Germany, 2017.

10. Christoffels, E.; Brunsch, A.; Wunderlich-Pfeiffer, J.; Mertens, F.M. Monitoring micropollutants in the Swist river basin. Water Sci. Technol. 2016, 74, 2280-2296. [CrossRef] [PubMed]

11. Benotti, M.J.; Brownawell, B.J. Distributions of Pharmaceuticals in an Urban Estuary during both Dry- and Wet-Weather Conditions. Environ. Sci. Technol. 2007, 41, 5795-5802. [CrossRef] [PubMed]

12. Wittmer, I.K.; Bader, H.-P.; Scheidegger, R.; Singer, H.; Lück, A.; Hanke, I.; Carlsson, C.; Stamm, C. Significance of urban and agricultural land use for biocide and pesticide dynamics in surface waters. Water Res. 2010, 44, 2850-2862. [CrossRef] [PubMed]

13. Munro, K.; Martins, C.P.B.; Loewenthal, M.; Comber, S.; Cowan, D.A.; Pereira, L.; Barron, L.P. Evaluation of combined sewer overflow impacts on short-term pharmaceutical and illicit drug occurrence in a heavily urbanised tidal river catchment (London, UK). Sci. Total Environ. 2019, 657, 1099-1111. [CrossRef] [PubMed]

14. Spahr, S.; Teixidó, M.; Sedlak, D.L.; Luthy, R.G. Hydrophilic trace organic contaminants in urban stormwater: Occurrence, toxicological relevance, and the need to enhance green stormwater infrastructure. Environ. Sci. Water Res. Technol. 2020, 6, 15-44. [CrossRef] 
15. Clara, M.; Gruber, G.; Humer, F.; Hofer, T.; Kretschmer, F.; Ertl, T.; Scheffknecht, G.; Giselbrecht, G.; Windhofer, G. Spurenstoffemissionen aus Siedlungsgebieten und von Verkehrsflächen in Österreich. In Proceedings of the Abwasserkolloquium 2017, Spurenstoffe im Regen- und Mischwasserabfluss, Stuttgart, Germany, 26 October 2017; pp. 59-76.

16. Launay, M.; Dittmer, U.; Steinmetz, H. Organic micropollutants discharged by combined sewer overflows-Characterisation of pollutant sources and stormwater-related processes. Water Res. 2016, 104, 82-92. [CrossRef] [PubMed]

17. Gasperi, J.; Sebastian, C.; Ruban, V.; Delamain, M.; Percot, S.; Wiest, L.; Mirande, C.; Caupos, E.; Demare, D.; Kessoo, M.D.K.; et al. Micropollutants in urban stormwater: Occurrence, concentrations, and atmospheric contributions for a wide range of contaminants in three French catchments. Environ. Sci. Pollut. Res. 2014, 21, 5267-5281. [CrossRef]

18. Birch, H.; Mikkelsen, P.S.; Jensen, J.K.; Lutzhoft, H.-C.H. Micropollutants in stormwater runoff and combined sewer overflow in the Copenhagen area, Denmark. Water Sci. Technol. 2011, 64, 485-493. [CrossRef]

19. Bollmann, U.E.; Vollertsen, J.; Carmeliet, J.; Bester, K. Dynamics of biocide emissions from buildings in a suburban stormwater Catchment-Concentrations, mass loads and emission processes. Water Res. 2014, 56, 66-76. [CrossRef]

20. Mutzner, L.; Vermeirssen, E.L.M.; Mangold, S.; Maurer, M.; Scheidegger, A.; Singer, H.; Booij, K.; Ort, C. Passive samplers to quantify micropollutants in sewer overflows: Accumulation behaviour and field validation for short pollution events. Water Res. 2019, 160, 350-360. [CrossRef]

21. Gamerith, V. High Resolution Online Data in Sewer Quality Modelling. Ph.D. Thesis, Technische Universität Graz, Graz, Austria, 2011.

22. Braud, I.; Fletcher, T.D.; Andrieu, H. Hydrology of peri-urban catchments: Processes and modelling. J. Hydrol. 2013, 485, 1-4. [CrossRef]

23. Furusho, C.; Chancibault, K.; Andrieu, H. Adapting the coupled hydrological model ISBA-TOPMODEL to the long-term hydrological cycles of suburban rivers: Evaluation and sensitivity analysis. J. Hydrol. 2013, 485, 139-147. [CrossRef]

24. Bach, M.; Ostrowski, M. Analysis of intensively used catchments based on integrated modelling. J. Hydrol. 2013, 485, 148-161. [CrossRef]

25. Musolff, A.; Leschik, S.; Möder, M.; Strauch, G.; Reinstorf, F.; Schirmer, M. Temporal and spatial patterns of micropollutants in urban receiving waters. Environ. Pollut. 2009, 157, 3069-3077. [CrossRef]

26. Haile, M.G. Accounting for Uncertainties in Combined Sewer Overflow Modelling. Ph.D. Thesis, Oldenburg Industrieverlag GmbH, München, Germany, 2016.

27. EPA. SWMM; United States Environmental Protection Agency: Washington, DC, USA, 2014.

28. Rossmann, L.; Huber, W. Storm Water Management Model Reference Manual Volume III-Water Quality. US EPA, Office of Research and Development, NRMRL, Water Supply and Water Resources Division. EPA/600/R-16/093; 2016. Available online: https://nepis.epa.gov/Exe/ZyPDF.cgi/P100P2NY.PDF?Dockey= P100P2NY.PDF (accessed on 24 October 2018).

29. Launay, M.; Steinmetz, H.; Dittmer, U. Organic micropollutants discharged by combined sewer overflows (CSOs): What about inter- and intra-event variability? In Proceedings of the 14th International Conference on Urban Drainage, ICUD, Prague, Czech Republic, 10-15 September 2017.

30. Wicke, D.; Matzinger, A.; Caradot, N.; Schubert, R.-L.; Sonnenberg, H.; von Seggern, D.; Heinzmann, B.; Rouault, P. Spurenstoffemissionen im Regenwasserabfluss Berlins. In Proceedings of the Abwasserkolloquium 2017, Spurenstoffe im Regen- und Mischwasserabfluss, Stuttgart, Germany, 26 October 2017; pp. $33-42$.

31. Fletcher, C.A.; Scrimshaw, M.D.; Lester, J.N. Transport of mecoprop from agricultural soils to an adjacent salt marsh. Mar. Pollut. Bull. 2004, 48, 313-320. [CrossRef] [PubMed]

32. Tu, M.-C.; Smith, P. Modeling Pollutant Buildup and Washoff Parameters for SWMM Based on Land Use in a Semiarid Urban Watershed. Water Air Soil Pollut. 2018, 229, 18. [CrossRef]

33. Siewicki, T.C. Environmental modeling and exposure assessment of sediment-associated fluoranthene in a small, urbanized, non-riverine estuary. J. Exp. Mar. Biol. Ecol. 1997, 213, 71-94. [CrossRef]

34. Musolff, A.; Leschik, S.; Reinstorf, F.; Strauch, G.; Schirmer, M. Micropollutant loads in the urban water cycle. Environ. Sci. Technol. 2010, 44, 4877-4883. [CrossRef] 
35. Madoux-Humery, A.-S.; Dorner, S.; Sauvé, S.; Aboulfadl, K.; Galarneau, M.; Servais, P.; Prévost, M. Temporal variability of combined sewer overflow contaminants: Evaluation of wastewater micropollutants as tracers of fecal contamination. Water Res. 2013, 47, 4370-4382. [CrossRef] [PubMed]

36. Passerat, J.; Ouattara, N.K.; Mouchel, J.-M.; Rocher, V.; Servais, P. Impact of an intense combined sewer overflow event on the microbiological water quality of the Seine River. Water Res. 2011, 45, 893-903. [CrossRef] [PubMed]

37. Björklund, K.; Cousins, A.P.; Strömvall, A.-M.; Malmqvist, P.-A. Phthalates and nonylphenols in urban runoff: Occurrence, distribution and area emission factors. Sci. Total Environ. 2009, 407, 4665-4672. [CrossRef]

38. Kalmykova, Y.; Björklund, K.; Strömvall, A.-M.; Blom, L. Partitioning of polycyclic aromatic hydrocarbons, alkylphenols, bisphenol A and phthalates in landfill leachates and stormwater. Water Res. 2013, 47, 1317-1328. [CrossRef]

39. Wicke, D.; Matzinger, A.; Rouault, P. Relevanz Organischer Spurenstoffe im Regenwasserabfluss Berlins-OgRe; Abschlussbericht; Kompetenzzentrum Wasser Berlin: Berlin, Germany, 2015.

(C) 2020 by the authors. Licensee MDPI, Basel, Switzerland. This article is an open access article distributed under the terms and conditions of the Creative Commons Attribution (CC BY) license (http://creativecommons.org/licenses/by/4.0/). 